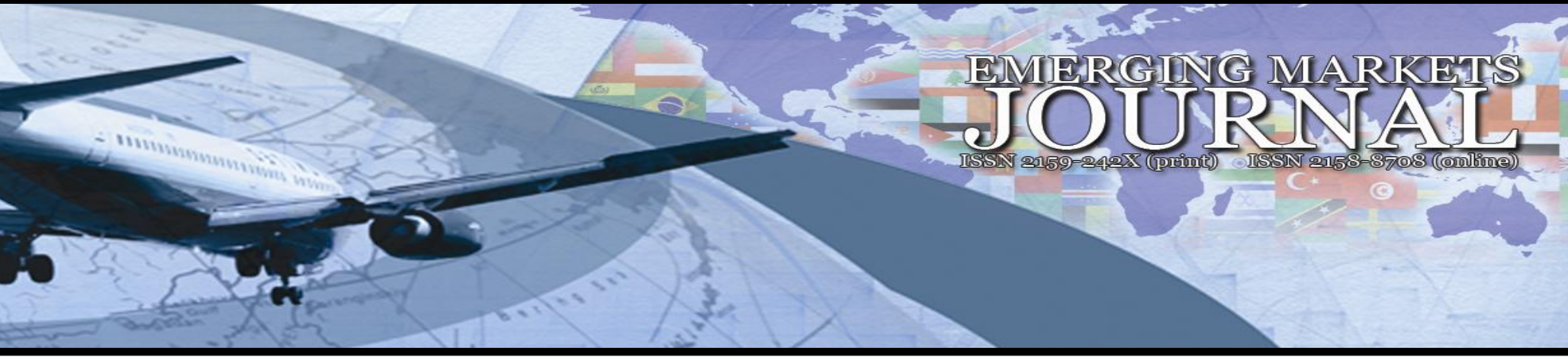

\title{
An Analysis of the Relationship between IFAC Code of Ethics and CPI
}

\section{Ayşe İrem Keskin}

Ph.D., Kadir Has University, Turkey | e-mail: ayseirem@hotmail.com

\section{Elçin Yılmaz Ișık}

Ph.D., Kadir Has Univerity, Turkey | e-mail: elcinyilmaz@gmail.com

Volume 5 No 2 (2015) ｜ＩSSN 2158-8708 (online) ｜ＤOI 10.5195/emaj.2015.81 | http://emaj.pitt.edu |

\begin{abstract}
Code of ethics has become a significant concept as regards to the business world. That is why occupational organizations have developed their own codes of ethics over time. In this study, primarily the compatibility classification of the accounting code of ethics belonging to the IFAC (The International Federation of Accountants) is carried out on the basis of the action plans assessing the levels of usage by the 175 IFAC national accounting organizations. It is determined as a result of the classification that $60,6 \%$ of the member organizations are applying the IFAC code in general, the rest $39,4 \%$ on the other hand, is not applying the code at all. With this classification, the hypothesis propounding that "The national accounting organizations in highly corrupt countries would be less likely to adopt the IFAC ethic code than those in very clean countries," is tested using the "Corruption Perception Index-CPI" data. It is determined that the findings support this relevant hypothesis.
\end{abstract}

\section{$(\mathrm{cc}) \mathrm{BY}$}

New articles in this journal are licensed under a Creative Commons Attribution 3.0 United States License.

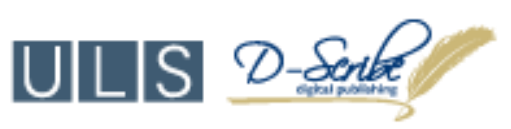

This journal is published by the University Library System of the University of Pittsburgh as part of its D-Scribe Digital Publishing Program, and is cosponsored by the University of Pittsburgh Press. 


\section{An Analysis of the Relationship between IFAC Code of Ethics and CPI}

\author{
Ayşe İrem Keskin \\ Elçin Yılmaz Işık
}

\section{Introduction}

The issue of ethics has increasingly become an important field of study as regards to the business behavior in enterprises. A number of companies, various educational institutions and occupational organizations show a high level of interest to the subject. When ethics is considered to be the code of conducts internalized by the society, it becomes evident that it is necessary for all the organizations which interact with their close circles to act sensitively in terms of ethical standards. Taylor (1975) defines ethics as an "inquiry into the nature and grounds of morality"; Barry (1979), on the other hand, defines the concept as "the study of what constitutes good and bad human conduct, including related actions and value."

The fundamental function of the code of ethics is to influence people in their decision-making processes to show a tendency to take decisions which are acceptable by the organization (Ferrell and Fraedrich, 1991). The code of ethics incorporates the responsibilities that the company management has towards its shareholders, in other words, briefly the environment they act in; and provides standards indicating what is within the line of "right and acceptable course of conduct" definition.

When the international accounting code of ethics is reviewed, The International Federation of Accountants (IFAC) contributes to the development, adoption and implementation of high quality ethical standards for the accountants through the International Ethics Standards Board for Accountants' (IESBA) support (IESBA, 2). IESBA's long-term objective is to converge the rule of code of ethics, which is valid for the accountants, with the standards published by the regulators and standard setters. Convergence to only one set of standards may well increase the quality and consistency of the services provided by the accountants all over the world, and improve the efficiency of the global capital markets (IESBA, 1).

The code of ethics for the IESBA accountants is composed of three major parts: (IESBA, 5)

- $\quad$ General Application of the Code
- $\quad$ Professional Accountants in Public Practice
-

- $\quad$ Professional Accountants in Business

\section{Literature Review}

It can be deduced from the literature review that the codes of ethics are prevalently used in businesses and subjected to research as regards to many aspects (Farrell and Farrell, 1998). While Hite et al. (1988), Schlegelmich and Houston (1989), Pelfrey and Peacock (1991) refer to the content and scope of the code of ethics in their studies, certain other scholars scrutinize the level of usage of code of ethics by companies on country basis (Farrel and Cobbin, 2000). Pelfrey and Peacock (1991) have found out in their studies that $50 \%$ of the companies within Fortune 500 in the U.S.A. have their own codes of ethics. This rate is expressed to be $41 \%$ for Europe by Langlois and Schlegelmilch (1990), and 50\% for Australia by Farrel and Cobbin (1996) (Farrel Farrel, 1998). Langlois and Schlegelmich (1990) have compared 600 European companies with their American counterparts in their studies, and explicated that the code of ethics in Europe started to be used later than their counterparts in the U.S.A., and there are certain indications suggesting that the European codes were inspired from the American codes of ethics. Aydınlık and Dönmez (2006) have drawn the conclusion from their studies they conducted in Turkey that the codes of ethics are being used in low rates within the country.

When relevant studies are examined, various other studies, through which the codes of ethics are scrutinized with respect to socio-cultural perspective, are acquired. Cohen, Laurie and Sharp (1992) have underlined the impact of the socio-economic and cultural factors on the acceptance and national application of code of ethics. Similarly, Clements, Neill, Stovall (2008) examined the impact of the socio-cultural factors on the decision to apply the codes of ethics relevant to the International Federation of Accountants-IFAC in the accounting organizations of countries on the basis of Hofstede's study, which includes cultural dimensions, as well. In another study, on the other hand, even though the countries have similar moral values, the challenges they come across in the developing international environment while taking decisions in the inter-cultural management because of the practical differences are underlined and a model is proposed for the inter-cultural ethical dichotomies (Wines, Napier, 1992).

Another area of analysis is relevant to the language of the codes of ethics. Attention is drawn to the fact that the grammatical structures used in the codes create a powerful sense of obligation and constitute an impediment to take decisions with free will. It is further elaborated in this study that the written codes shall not include complicated messages other than those aimed to be communicated (Farrell, Cobbin 2000).

Another point of view for the codes of ethics, on the other hand, is framed on the comparative analysis of the codes of ethics belonging to national occupational 
organizations. In their study, Cobbin and Farrell (2000) have determined the fundamental features of the codes of ethics adopted by 57 national occupational organizations of accountants, elaborated on the naming of the codes, and examining their contents. Additionally, different integrated code types (allodial and decretal) utilized by the national occupational organizations are determined in this study, and the level of these codes' congruence with the code of ethics published by IFAC is detected. Cobbin and Farrell (2000)'s study demonstrate that "most of the respondents' codes were decretal, rule-based in content (96\%), with varying amounts of allodial material incorporated" and "the position taken by IFAC in selecting a decretal code (with inspirational content) is congruent with the codes analyzed in this research."

Another research conducted on this issue by Cobbin and Farrell (2000) includes the analysis of ethical environment of the international accounting occupation. The objective of the research, which is based on the mainstreaming research model, is to determine the importance the national occupational organizations attribute to ethics, as a group.

Yet another research is on the comparison of the English translations of the code of ethics proposed by the occupational organizations of 28 countries and provision of a general perspective as regards to the code of ethics (Shachaf, 2005). This relevant study reveals the principles of code of ethics regulated as 20 different categories. The most frequently used ones of these codes are professional competency, honesty, confidentiality, and free and equal access to information.

Another study about the subject is on the analysis of the international accounting code of ethics. This study is carried out through 158 national accounting organizations. 80 of these organizations have been applying the IFAC codes as they are (with a slight modification under certain circumstances), and 78 of them have chosen not to use the IFAC code as a model. After making the necessary distinction, the researchers tested the hypothesis that countries with lower income levels are less willing to apply the IFAC code. The findings did not support the hypothesis. The reason for that is propounded to be the fact that applying the IFAC code was way less costlier for a country with low income level than creating a new code of ethics (Clements, Neill, Stovall, 2009).

As to the concept of corruption Macrea (1982, 678) defined it as an agreement that leads to exchanges between two people (supplier and demandant). According to Macrea, this agreement has an impact on the distribution of resources immediately or in near future, and includes abuse of common responsibilities or public resources for an individual desire. Stapenhurst (2000) and Worldbank (1997) defined corruption in the simplest term as personal gain or abuse of public force to gain favor for a group to which the perpetrator is affiliated. Tanzi (1998) mentioned that it should not be deduced from this definition that there is not any corruption in the private sector activities. He further asserted that there is evident corruption in processes such as recruitment or purchasing especially in large-scale private enterprises.

Worldbank (1997) stated that corruption always results from the policies, bureaucratic traditions, political development and social histories of the countries. Although Husted (1999) uttered in many of his hypotheses that the reasons of corruption are economic and political factors; he stated that economic, political, cultural and psychological factors should be concomitantly examined by theoreticians while seeking the reasons for corruption.

Corruption Perception Index (CPI) is an index published regularly -every year- by a research company named as Transparency International as of 1995. The corruption perceptions in countries are determined in the index as a result of the expert opinions and public opinion polls. CPI is a composite indicator used to measure the public sector corruption perception in different countries all over the world (TI, Technical Methodology Note, 1). It is a composite index based on individual researches from various sources (Saha, Gounder and Jen-Je Su, 2012). The power of the CPI comes from the usage of more than one year averages increasing the reliability of the index, and provision of the data from various sources (Selingson, 2006). The index methodology is composed of four fundamental phases being the selection of the source data, re-scaling of the source data, combining the re-scaled source data, and reporting the measurement of uncertainty (TI, Technical Methodology Note, 1).

CPI 2014 is calculated through using 12 different source data from 11 different organizations. The standardization of the source data are carried out through a scaling from 0 to 100.0 indicates highest level of corruption, and 100 indicates the lowest level of corruption (TI, Short Methodology Note, 1).

\section{Research and Empirical Results}

The classification of countries applying the IFAC code, which is one of the variables in Clements, Neill, Stovall's (2009) studies, is updated in the light of the studies conducted by the IFAC in 2013-2014 and expanded to include the numbers of countries, and occupational organizations in the first part of the study. Thereby, the development of the IFAC code of ethics used by the different countries' accounting organizations within years is determined. 
Following that, the Corruption Perception Index-CPI is incorporated into the study. In this analysis, the national occupational organizations applying the IFAC code as it is or with slight modifications and other organizations which do not apply the IFAC code are compared on the basis of the corruption perception index. In this sense, an analysis is carried out in order to determine whether there is any difference in the application of the IFAC code by the countries taking place in the upper and lower levels of the corruption perception index.

The data as regards to the application of the IFAC code of ethics by the occupational organizations are acquired from the IFAC's website. Statement of Member Obligations-SMO Action Plan covering the years of 2013-2014 is benefited to obtain the relevant data. This action plan can be deemed to be a continuation of the previous surveys conducted in the field and is composed of 7 chapters. The $4^{\text {th }}$ chapter, IESBA Code of Ethics, is used in this study. IESBA Code of Ethics data are gathered from 179 member and associate member organizations. Some of these organizations apply the IFAC code, while others do not. Action plans are studies prepared and declared by the national accounting organizations themselves.

Although it is determined whether the IFAC code is used by the organizations through benefiting from the action plans; the organizations are grouped via taking the classifications, including the level of usage of the IFAC code by the organizations as a reference. These classifications are presented in the aforesaid surveys in the IFAC website.

Transparency International's corruption perception index (CPI) of 2014 data are also categorized. 4 of the countries within the 179 member and associate member organizations are not evaluated in the CPI. These countries are Brunei Darussalam, Fiji, Palestinian Territory Occupied and Cayman Islands. Therefore, occupational organizations belonging to these four countries are excluded from the list in the analysis of the relationship between the CPI and Code of Ethics.

\section{Table 1: Accounting Organizations that Completely} Apply the IFAC Code of Ethics

\begin{tabular}{|c|c|}
\hline & COUNTRY \\
\hline 1 & ALBANIA \\
\hline 2 & ARMENIA \\
\hline & $\begin{array}{l}\text { AZERBAIJAN } \\
\text { BAHAMAS }\end{array}$ \\
\hline & $\begin{array}{l}\text { BAHAMAS } \\
\text { BANGLADESH }\end{array}$ \\
\hline & BANGLADESH \\
\hline 8 & BARBADOS \\
\hline & BOLIVIA \\
\hline $\begin{array}{l}9 \\
10\end{array}$ & $\begin{array}{l}\text { BUSNIA AND HERZEOVINA } \\
\text { BOSNIA AND HERZEGIN }\end{array}$ \\
\hline 11 & BOTSWANA \\
\hline 12 & BULGARIA \\
\hline $\begin{array}{l}13 \\
14\end{array}$ & CAMBODIA \\
\hline $\begin{array}{l}14 \\
15\end{array}$ & COLOMBIA \\
\hline 16 & COTE D'IVOIRE \\
\hline $\begin{array}{l}17 \\
18\end{array}$ & CROATIA \\
\hline $\begin{array}{l}18 \\
19\end{array}$ & $\begin{array}{l}\text { CYPRUS } \\
\text { CZECH REPUBLIC }\end{array}$ \\
\hline 20 & CZECH REPUBLIC \\
\hline 21 & $\begin{array}{l}\text { DENMARK } \\
\text { EL SALVADOR }\end{array}$ \\
\hline 23 & FINLAND \\
\hline 24 & FINLAND \\
\hline $\begin{array}{l}25 \\
26\end{array}$ & GEORGIA \\
\hline 27 & $\begin{array}{l}\text { GHAINA } \\
\text { GREECE }\end{array}$ \\
\hline 28 & ICELAND \\
\hline 29 & IRELAND \\
\hline $\begin{array}{l}30 \\
31\end{array}$ & JAMAICA \\
\hline 32 & JORDAN \\
\hline $\begin{array}{l}33 \\
34\end{array}$ & KAZAKHSTAN \\
\hline $\begin{array}{l}34 \\
35\end{array}$ & KAZAKHSTAN \\
\hline $\begin{array}{l}35 \\
36\end{array}$ & KOREA. REPUBLIC OF \\
\hline $\begin{array}{l}36 \\
37\end{array}$ & $\begin{array}{l}\text { KOSOVO } \\
\text { KYRGYZSTAN }\end{array}$ \\
\hline 38 & LATVIA \\
\hline 39 & LEBANON \\
\hline 40 & MACEDONIA, THE FORMER YUGOSLAV \\
\hline 41 & MALAWI \\
\hline 42 & MAURITIUS \\
\hline $\begin{array}{l}43 \\
44\end{array}$ & $\begin{array}{l}\text { MOLDOVA, REPUBLIC OF } \\
\text { MONTENEGRO (REPUBLIC OF) }\end{array}$ \\
\hline 45 & MONTENEGRO (REPUBLIC OF) \\
\hline 46 & NIGERIA \\
\hline 47 & PAPUA NEW GUINEA \\
\hline $\begin{array}{l}48 \\
49\end{array}$ & PARAGUAY \\
\hline $\begin{array}{l}49 \\
50\end{array}$ & POLAND \\
\hline 51 & ROMANIA \\
\hline 52 & SERBIA (REPUBLIC OF) \\
\hline $\begin{array}{l}53 \\
54\end{array}$ & $\begin{array}{l}\text { SIERRA LEONE } \\
\text { SLOVAKIA }\end{array}$ \\
\hline 55 & SLOVENIA \\
\hline 56 & SOUTH AFRICA \\
\hline 57 & SWAZILAND \\
\hline 58 & $\begin{array}{l}\text { SWEDEN } \\
\text { SWITZFRIAND }\end{array}$ \\
\hline $\begin{array}{l}59 \\
60\end{array}$ & $\begin{array}{l}\text { SWITZERLAND } \\
\text { TANZANIA, UNITED REPUBLIC OF }\end{array}$ \\
\hline $\begin{array}{l}61 \\
62\end{array}$ & THAILAND \\
\hline $\begin{array}{l}62 \\
63\end{array}$ & $\begin{array}{l}\text { TOGO } \\
\text { TRINIDAD AND TOBAGO }\end{array}$ \\
\hline 64 & TURKEY \\
\hline 65 & TURKEY \\
\hline 66 & UKRAINE \\
\hline $\begin{array}{l}67 \\
68\end{array}$ & UKRAINE \\
\hline $\begin{array}{l}68 \\
69\end{array}$ & $\begin{array}{l}\text { UNITED KINGDOM } \\
\text { UNITED KINGDOM }\end{array}$ \\
\hline 69 & $\begin{array}{l}\text { UNITED KINGDOM } \\
\text { UNITED KINGDOM }\end{array}$ \\
\hline 71 & URUGUAY \\
\hline 72 & UZBEKISTAN \\
\hline $\begin{array}{l}73 \\
74\end{array}$ & UZBEKISTAN \\
\hline & ZIMBABWE \\
\hline
\end{tabular}

\section{ORGANIZATIO}

Albanian Institute of Certified Accountants Association of Accountants and Auditors of Armenia The Chamber of Auditors of Azerbaiian Republic The Bahamas Institute of Chartered Accountants The Institute of cost and Manauntants of Banaladesh The Institute of Chartered Accountants of Barbados Coleaio de Auditores de Bolivia

Association of Accountants and Auditors of Republic of Srpska Union of Accountants. Auditors and Financial Workers of Botswana Institute of Chartered Accountants Institute of Certified Public Accountants of Bulqaria Kampuchea Institute of Certified Public Accountants an The Institute of Chartered Accountants of Cameroon Ordre des Experts Comptables et Comptables Aqréés de Côte Croatian Audit Chamber

The Institute of Certified Public Accountants of Cvorus Chamber of Auditors of the Czech Republic

Union of Accountants of the Czech Republic

FSR - danske revisorer

Instituto Salvadoreño de Contadores Públicos (ISCP) HTM-tilintarkastaiat rV - GRM- revisorer if KHT-vhdistvs-Föreninaen CGR rv

Georaian Federation of Professional Accountants and Auditors The Institute of Chartered Accountants (Ghana)

Institute of Certified Public Accountants of Greece (SOEL) Felaa Loaailtra Endurskodenda

Accountants in Ireland

The Institute of Chartered Accountants of Jamaica

Jordanian Association of Certified Public Accountants Chamber of Professional Accountants of the Republic of Chamber of Auditors of the Republic of Kazakhsta . Societr of Certified Accountants and Auditors of Kosovo hiton Lebanese Association of Certified Public Accountants

Institute of Certified Auditors of the Republic of Macedoni The Societv of Accountants in Malaw Mauritius Institute of Professional Accountants Association of Professional Accountants \& Auditors of the Institute of Certified Accountants of Montenearo (ICAM) Institute of Accountants and Auditors of Montenearo Association of National Accountants of Niqeria Certified Practisina Accountants Papua New Guine Coleaio de Contadores de Paraquav

Junta de Decanos de Coleaios de Contadores Publicos del Peru Auditors

The Chamber of Financial Auditors of Romania The Institute of Chartered Accountants of Sierra Leone, Slovenska Komora Auditorov

The Slovenian Institute of Auditors

The South African Institute of Chartered Accountants Swaziland Institute of Accountants

Treuhand-Kammer -Swiss Institute of Certified Accountants Fional Board of Accountants and Auditors (NBAA)

Federation of Accountina Professions

Ordre National des Experts-Combtables et Comptables Aaréés The Institute of Chartered Accountants of Tri

Union of Chambers of Certified Public Accountants of Turke Ukrainian Association of Certified Accountants and Auditors Ukrainian Federation of Professional Accountants and Auditors Institute of Financial Accountan

The Chartered Institute of Manaaement Accountants (CIMA) The Chartered Institute of Public Finance and Accountancy Chamber of Auditors of Uzbekistan

National Association of Accountants and Auditors of Uzbekistan Zambia Institute of Chartered Accountants

Source: IFAC: 2014, "Compliance Responses and

Action Plans", https://www.ifac.org/about-

ifac/membership/compliance-program/compliance-

responses. 
Table 2: Accounting Organizations that Apply the IFAC Code of Ethics with Slight Modifications

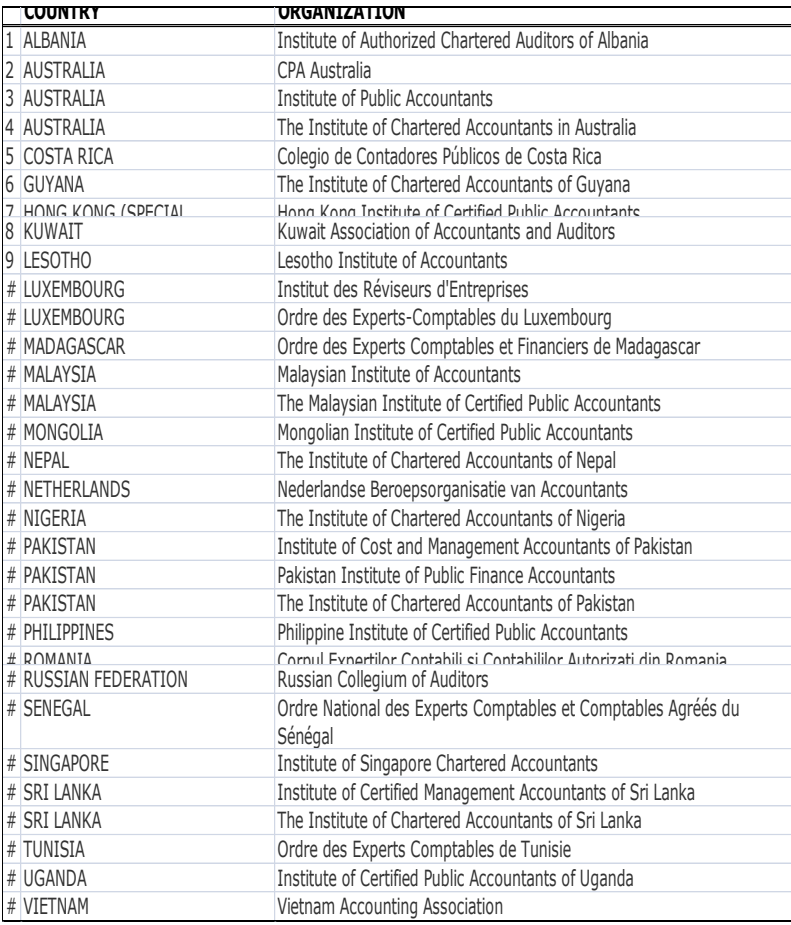

Source: IFAC: 2014, "Compliance Responses and Action Plans", https://www.ifac.org/aboutifac/membership/compliance-program/complianceresponses.

As can be seen from Table 1, 75 of the 175 IFAC member occupational organizations apply the IFAC rules without modifications. 31 national accounting organizations are presented in Table 2. These national accounting organizations apply the IFAC ethic codes with slight modifications. Although the 54 organizations, which are IFAC members, presented in Table 3 have their own ethic codes, they plan to converge their codes to the IFAC code or change their ethic codes completely with the IFAC code in the long term. 7 accounting organizations are presented in Table 4. These organizations use their own ethical requirements and have different approach to the usage of IFAC code of ethics. None of the 8 accounting organizations presented in Table 5 applies the IFAC code or plans to converge its code to the IFAC code or use the code completely on future dates. The rate of the occupational organizations completely applying the IFAC rules in totally 175 occupational organizations is $42.9 \%$. The rate of the ones applying the IFAC ethic codes with slight modifications is $17.7 \%$. The rate of the organizations that have used their own ethical requirements with a process to eliminate differences between their ethical requirements and the IFAC code of ethics is $30.8 \%$. The rate of the organizations that use their own ethical requirements and have different approach to the usage of the IFAC code of ethics, on the other hand, is $4 \%$. The rate of the organizations that do not apply the IFAC code or plan to converge their codes to the IFAC code or use the code completely on future dates is $4.6 \%$. Consequently, the total number of occupational organizations generally applying the IFAC code is 106 . This constitutes $60.6 \%$ of all the occupational organizations. The total number of occupational organizations that generally do not apply the IFAC code is 69 and constitutes $39.4 \%$ of all the occupational organizations.

\section{Table 3: Accounting Organizations that Plan to Converge to or Completely Apply the IFAC Code of Ethics}

\begin{tabular}{|c|c|c|}
\hline & COUNTRY & ORGANIZATION \\
\hline 1 & ARGENTINA & Federación Argentina de Consejos Profesionales de Ciencias Económicas \\
\hline 2 & AUSTRIA & Institut Österreichischer Wirtschaftsprüfer \\
\hline 3 & AUSTRIA & Kammer der Wirtschaftstreuhänder \\
\hline 4 & BAHRAIN & Bahrain Accountants Association \\
\hline 5 & BELGIUM & $\begin{array}{l}\text { Institut des Experts-comptables et des Conseils Fiscaux - Instituut Van de } \\
\text { Accountants en de Belastingconsulenten }\end{array}$ \\
\hline 6 & BELGIUM & Instituut van de Bedrijfsrevisoren - Institut des Réviseurs d'Entreprises \\
\hline 7 & BENIN & Ordre des Experts-Comptables et Comptables Agréés du Bénin (OECCA) \\
\hline 8 & BRAZIL & Conselho Federal de Contabilidade \\
\hline 9 & BRAZIL & Instituto dos Auditores Independentes do Brasil \\
\hline 10 & CANADA & Certified General Accountants Association of Canada \\
\hline 11 & CANADA & $\begin{array}{l}\text { Certified Management Accountants of Canada (Now operating as CPA Canada - } \\
\text { effective April 1, 2013) }\end{array}$ \\
\hline 12 & CANADA & $\begin{array}{l}\text { The Canadian Institute of Chartered Accountants (Now operating as CPA Canada - } \\
\text { effective April 1, 2013) }\end{array}$ \\
\hline 13 & CHILE & Colegio de Contadores de Chile \\
\hline 14 & CHINA & The Chinese Institute of Certified Public Accountants \\
\hline 15 & CHINESE TAIWAN & Federation of CPA Associations of Chinese Taiwan \\
\hline 16 & CROATIA & Croatian Association of Accountants and Financial Experts \\
\hline 17 & DOMINICAN REPUBLIC & Instituto de Contadores Públicos Autorizados de la República Dominicana \\
\hline 18 & EGYPT & The Egyptian Society of Accountants \& Auditors \\
\hline 19 & ESTONIA & Estonian Association of Auditors \\
\hline 20 & GERMANY & Wirtschaftsprüferkammer \\
\hline 21 & GUATEMALA & Instituto Guatemalteco de Contadores Públicos y Auditores \\
\hline 22 & HAITI & Ordre des Comptables Professionels Agrees d'Haiti \\
\hline 23 & HUNGARY & Chamber of Hungarian Auditors \\
\hline 24 & INDIA & The Institute of Cost Accountants of India \\
\hline 25 & INDIA & The Institute of Chartered Accountants of India \\
\hline 26 & $\begin{array}{l}\text { IRAN (ISLAMIC } \\
\text { REPUBLIC OF) }\end{array}$ & Iranian Association of Certified Public Accountants \\
\hline 27 & $\begin{array}{l}\text { IRAN (ISLAMIC } \\
\text { REPUBLIC OF) }\end{array}$ & The Iranian Institute of Certified Accountants \\
\hline 28 & IRAQ & Iraqi Union of Accountants and Auditors \\
\hline 29 & IRELAND & Accounting Technicians Ireland \\
\hline 30 & IRELAND & Chartered Accountants Ireland \\
\hline 31 & ISRAEL & Institute of Certified Public Accountants in Israel \\
\hline 32 & ITALY & Consiglio Nazionale dei Dottori Commercialisti e degli Esperti Contabili \\
\hline 33 & LATVIA & Association of Accountants of the Republic of Latvia \\
\hline 34 & MALTA & The Malta Institute of Accountants \\
\hline 35 & MEXICO & Instituto Mexicano de Contadores Públicos, A.C. \\
\hline 36 & MOROCCO & Ordre des Experts Comptables du Royaume du Maroc \\
\hline 37 & NAMIBIA & Institute of Chartered Accountants of Namibia \\
\hline 38 & NEW ZEALAND & New Zealand Institute of Chartered Accountants \\
\hline 39 & NICARAGUA & Colegio de Contadores Públicos de Nicaragua \\
\hline 40 & NORWAY & Den Norske Revisorforening (DnR) \\
\hline 41 & PANAMA & Colegio de Contadores Públicos Autorizados de Panamá \\
\hline 42 & POLAND & Accountants Association in Poland \\
\hline 43 & PORTUGAL & Ordem dos Revisores Oficiais de Contas (OROC) \\
\hline 44 & $\begin{array}{l}\text { RUSSIAN } \\
\text { FEDERATION }\end{array}$ & The Institute of Professional Auditors \\
\hline 45 & $\begin{array}{l}\text { RUSSIAN } \\
\text { FEDERATION }\end{array}$ & Moscow Audit Chamber \\
\hline 46 & $\begin{array}{l}\text { RUSSIAN } \\
\text { FEDERATION }\end{array}$ & Audit Chamber of Russia \\
\hline 47 & $\begin{array}{l}\text { RUSSIAN } \\
\text { FEDERATION }\end{array}$ & The Institute of Professional Accountants of Russia \\
\hline 48 & RWANDA & Institute of Certified Public Accountants of Rwanda \\
\hline 49 & SAUDI ARABIA & Saudi Organization for Certified Public Accountants \\
\hline 50 & SOUTH AFRICA & The South African Institute of Professional Accountants \\
\hline 51 & SRI LANKA & Association of Accounting Technicians of Sri Lanka \\
\hline 52 & UNITED KINGDOM & Association of Accounting Technicians (AAT) \\
\hline 53 & UNITED KINGDOM & The Institute of Chartered Accountants in England and Wales \\
\hline 54 & UNITED STATES & American Institute of Certified Public Accountants \\
\hline
\end{tabular}

Source: IFAC: 2014, "Compliance Responses and

Action Plans", https://www.ifac.org/about-

ifac/membership/compliance-program/complianceresponses. 
Table 4: Accounting Organizations that Have a different Approach to the Usage of IFAC Code of Ethics and Use their Own Code of Ethics

\begin{tabular}{|c|c|}
\hline COUNTRY & ORGANIZATION \\
\hline FRANCE & $\begin{array}{l}\text { Compagnie Nationale des Commissaires aux } \\
\text { Comptes }\end{array}$ \\
\hline FRANCE & $\begin{array}{l}\text { Conseil Supérieur de I'Ordre des Experts- } \\
\text { Comptables }\end{array}$ \\
\hline HONDURAS & $\begin{array}{l}\text { Colegio de Peritos Mercantiles y Contadores } \\
\text { Públicos }\end{array}$ \\
\hline INDONESIA & Ikatan Akuntan Indonesia \\
\hline LITHUANIA & Lithuanian Chamber of Auditors \\
\hline UNITED & Association of Chartered Certified \\
\hline $\begin{array}{l}\text { KINGDOM } \\
\text { UNITED }\end{array}$ & $\begin{array}{l}\text { Accountants (ACCA) } \\
\text { The Institute of Chartered Accountants of }\end{array}$ \\
\hline KINGDOM & Scotland \\
\hline
\end{tabular}

Source: IFAC: 2014, "Compliance Responses and Action Plans", https://www.ifac.org/aboutifac/membership/compliance-program/complianceresponses.

Table 5: Accounting Organizations that Do Not Apply and Consider Applying the IFAC Code of Ethics

\begin{tabular}{|ll|}
\hline COUNTRY & ORGANIZATION \\
\hline \hline 1 GERMANY & Institut der Wirtschaftsprüfer \\
\hline 2 GUATEMALA & Colegio de Contadores Publicos y Auditores de Guatemala \\
\hline 3 JORDAN & The Intemational Arab Society of Certified Accountants \\
\hline 4 KENYA & Institute of Certified Public Accountants of Kenya \\
\hline 5 LIBERIA & The Liberian Institute of Certified Public Accountants \\
\hline 6 PORTUGAL & Ordem dos Técnicos Oficiais de Contas \\
\hline 7 SPAIN & Instituto de Censores Jurados de Cuentas de España \\
\hline UNITED STATES & Institute of Management Accountants \\
\hline
\end{tabular}

Source: IFAC: 2014, "Compliance Responses and Action Plans", https://www.ifac.org/aboutifac/membership/compliance-program/complianceresponses.

All national accounting organizations are classified in 5 categories according to the Corruption Perception Index prepared by the non-governmental organizations (NGO) named as the "Transparency International the Global Coalition against Corruption." These 5 categories are acquired through dividing a 100-points scale into 20points sections. The first category between $0-20$ point intervals is identified as "highly corrupt." The second category of 20-40 points is identified as "corrupt." The third category of 40-60 points is identified as "neither clean nor corrupt." The fourth category of $60-80$ points is identified as "clean." And finally, the fifth category of $80-100$ is identified as "very clean."

Table 6 shows the results of the chi square $\mathrm{X}^{2}$ which examines whether the decision to apply the IFAC ethic code is influenced by the national corruption. The hypothesis of the research is "The national accounting organizations in highly corrupt countries would be less likely to adopt the IFAC ethic code than those in very clean countries".
Table 6: $\mathrm{X}^{2}$ Test of the Relationship between the IFAC Code Application and CPI

\begin{tabular}{|ll|r|r|r|}
\hline & & \multicolumn{2}{|c|}{ IFAC } & \multirow{2}{*}{ Total } \\
\cline { 3 - 5 } & & 1 & 2 & 4 \\
\hline CPI & 1 & 2 & 2 & 75 \\
& 2 & 51 & 24 & 44 \\
& 3 & 28 & 16 & 35 \\
& 4 & 13 & 22 & 17 \\
& 5 & 12 & 5 & 175 \\
\hline
\end{tabular}

$X^{2}=10,852$

$\mathrm{df}=4$

$\mathrm{p}=0,028$

It is observed that there is a statistically significant $(p=, 002)$ relationship between the usage of the IFAC Code by the national accounting organizations and corruption. Accordingly, the national accounting organizations in highly corrupt countries would be less likely to adopt the IFAC ethic code than those in very clean countries.

\section{CONCLUSION AND RECOMMENDATIONS}

The number of national accounting organizations that apply the IFAC ethic code has shown an increase compared to the past years. The number of these organizations is detected to be 106; therefore it is observed that $60.6 \%$ of the organizations apply the IFAC code completely or with slight modifications. 69 of the national accounting organizations, on the other hand, do not apply the IFAC ethic code. The relevant organizations constitute a rate of $39.4 \%$ in the grand total. Increasing usage of the IFAC ethic code by different accounting organizations in the future is within the bounds of possibility.

The hypothesis, which is articulated as "The national accounting organizations in highly corrupt countries would be less likely to adopt the IFAC ethic code than those in very clean countries," is supported by the research results.

Rules, laws and similar regulatory structures in countries, where the corruption level is observed to be lower, gain further acceptance in societies. This has provided an opportunity for the creation of ethical rules in the occupational organizations of the countries and application of these ethical rules as necessary. As a result, we believe that the acceptance of regulatory mechanisms such as IFAC code and its becoming functional for 
implementation will be way easier in countries that are distanced from corruption.

This study can comparatively be expanded to analyze the changes in the numbers of the organizations applying and not applying the IFAC code of ethics in the coming years and reveal the periodic differences between the current and future status.

\section{REFERENCES}

A. Ulgen A., Dönmez D., "Türkiye'de Faaliyet Gösteren En Büyük 500 İşletme'de Etik Kodlar Araştırması", Marmara Üniversitesi Sosyal Bilimler Enstitüsü Hakemli Dergisi: Öneri, Sayı:28, Y11:14, Cilt:7, Haziran 2007, 151-158.

Barry, V,: 1979, Moral Issues in Business (Wadsworth Publishing Co., New York), 39-70.

Clements, C. E., Neill, J., \& Stovall, O. S. (2009). An Analysis of International Accounting Codes of Conduct, Journal of Business Ethics. 87, 173-183 (a).

Clements, Curtis and Neill, John D. and Stovall, O. Scott (2008). The Impact of Cultural Differences on the Convergence of International Accounting Codes of Ethics (September 30, 2008). AAA 2009 MidYear International Accounting Section (IAS) Meeting. http://ssrn.com/abstract=1275950 (b).
Cohen, Jeffrey R. ; Pant, Laurie W. \& Sharp, David J. (1992). Cultural and socioeconomic constraints on international codes of ethics: Lessons from accounting. Journal of Business Ethics 11 (9), 687 - 700.

Farrell, B. and Cobbin, D. (2000), An analysis of the ethical environment of the international accounting profession. Business Ethics: A European Review, 9, 20-30.

Farrell, Brian; Cobbin, Deirdre. A content analysis of codes of ethics from fiftyseven national accounting organisations Business Ethics: A European Review. Jul2000, Vol. 9 Issue 3, 180190.

Farrell, H. And Farrell, B. J.: 1998 The Language of Business Codes of Ethics: Implications of Knowledge and Power Journal of Business Ethics 17: 587-601, Gluer Academic Publishers. Printed in the Netherlands.

Ferrell, O. C. And j. Fraedrich: 1991, Business Ethics: Ethical Decision Making and Cases (Houghton Mifflin Company, Boston), p. 60. 
"Helping Countries Combat Corruption: The Role of the World Bank," PREM Network, The World Bank, Washington, D.C., September 1997, http://www1.worldbank.org/publicsecto r/anticorrupt/corruptn/corrptn.pdf .

Hite, R., Bellizzi, J. and Fraser, C. 1988. 'A content analysis of ethical policy statements regarding marketing activities'. Journal of Business Ethics, 7:10, 771-776.

Husted, B.W. (1999). Wealth, Culture and Corruption. Journal of International Business Studies, Vol.30, No.2, 339359.

IESBA Handbook of the Code of Ethics for Professional Accountants 2014 Edition, http://www.ifac.org /sites/default/files/publications/files/201 4-IESBA-Handbook.pdf.

IFAC: 2014, "Compliance Responses and Action Plans", https://www.ifac.org/aboutifac/membership/complianceprogram/compliance-responses.

IFAC: 2015, "History", http://www.ifac.org/aboutifac/organization-overview/history.
Langlois, C. and Schlegelmilch, B. 1990, 'Do corporate codes of ethics reflect national character? Evidence from Europe and the United States'. Journal of International Business Studies, 21:4, 519-539.

Macrae,John.(1982).Underdevelopment and the Economics of corruption: A Game Theory Approach. World Development, Vol.10, No.88,pp. 677-687.

Pelfrey, S. and E. Peacock: 1991, 'Ethical Codes of Conduct Are Improving', Business Forum (Spring), 14-18.

Saha, Shrabani; Gounder, Rukmani; Jen-Je Su. Is There a "Consensus" Towards Transparency International's Corruption Perceptions Index?. International Journal of Business Studies. Dec2012, Vol. 19 Issue 2, 1-9.

Schlegelmilch, B. and J. Houston: 1989, 'Corporate Codes of Ethics in Large U.K. Companies: An Empirical Investigation of Use, Content and Attitudes', European journal of Marketing (U.K.) 23(6), 7-24. 
Seligson, Mitchell A.. In Part Special Issue (pp.

324-404). The Measurement and Impact of Corruption Victimization: Survey Evidence from Latin America. Corruption and Development: Analysis and Measurement , World Development. 2006 34(2):381-404.

Shachaf, P. (2005). A global perspective on library association codes of ethics. Library \& Information Science Research, 27(4), 513-533.

Stapenhurst, R. (2000). The media's role in curbing corruption [Working paper], World Bank Institute, World Bank.

Tanzi, V. (1998). Corruption around the world: Causes, consequences, scope, and cures [IMF working paper, 98/63]. Washington: International Monetary Fund.

Taylor, Paul W.; 1975, Principles of Ethic: An Introduction (Dickerson Publishing Co., Inc., Encino, California).

Transparency International. Corruption Perceptions Index 2014 Technical Methodology Note, http://www.transparency.org/cpi2014/in _detail 2015.
Transparency International. Corruption Perceptions Index 2014 Short Methodology Note, http://www.transparency.org/cpi2014/in _detail 2015.

Wines, William A. \& Napier, Nancy K. (1992). Toward an understanding of crosscultural ethics: A tentative model. Journal of Business Ethics 11 (11), $831-841$. 